Chapter Title: 'One Feels so Much in These Times!' Emotional Education and the

Construction of New Subjectivities: Sex Education Films in Early 1960s GDR

Chapter Author(s): Anja Laukötter

Book Title: Body, Capital, and Screens

Book Subtitle: Visual Media and the Healthy Self in the 20th Century

Book Editor(s): Christian Bonah, Anja Laukötter

Published by: Amsterdam University Press. (2020)

Stable URL: https://www.jstor.org/stable/j.ctv12sdvgj.11

JSTOR is a not-for-profit service that helps scholars, researchers, and students discover, use, and build upon a wide range of content in a trusted digital archive. We use information technology and tools to increase productivity and facilitate new forms of scholarship. For more information about JSTOR, please contact support@jstor.org.

Your use of the JSTOR archive indicates your acceptance of the Terms \& Conditions of Use, available at https://about.jstor.org/terms

This book is licensed under a Creative Commons Attribution-NonCommercialNoDerivatives 4.0 International License (CC BY-NC-ND 4.0). To view a copy of this license, visit https://creativecommons.org/licenses/by-nc-nd/4.0/.

Amsterdam University Press is collaborating with JSTOR to digitize, preserve and extend access to Body, Capital, and Screens 


\title{
7. 'One Feels so Much in These Times!' Emotional Education and the Construction of New Subjectivities: Sex Education Films in Early 196os GDR
}

\author{
Anja Laukötter
}

\begin{abstract}
Shown in different formats - from cinema to television - in a variety of settings, this chapter outlines the role these films played in discourses on sex education in the GDR in the 1960 , which for their part were highly influenced by psychology and pedagogy. The article will argue that these films not only served the pedagogical function of teaching viewers about sexuality, but also aimed to (re-)produce the ideal of the 'new man' for a newly emerging socialist society that was to be founded on a new way of educating emotions. Since the education of youth was regarded a key issue for the construction of new selves, the medium of film with its special attractiveness for the young generation can be viewed as an instrument for forming new subjectivities.
\end{abstract}

Keywords: sex education; television; GDR; West Germany; emotion/feeling; sexuality; pedagogy; child; parents; teacher/educator; filmic techniques

\section{Introduction}

Anita runs home crying and throws herself onto the sofa. Her mother enters the room and asks 'What's the matter?', but Anita keeps crying. Her father chimes in: 'Every day it's the same drama.' The mother asks her husband: 'Do you understand all this?' Tracking shot through an empty classroom. 'Anita loves Peter' is written on the blackboard. Voice-over: 'Eleven- and twelve-year-old boys and girls sit in this classroom. Last month, three vulgar

Bonah, C. and A. Laukötter (eds.), Body, Capital, and Screens: Visual Media and the Healthy Self in the 2oth Century. Amsterdam: Amsterdam University Press, 2020 DOI 10.5117/9789462988293_CHO7 

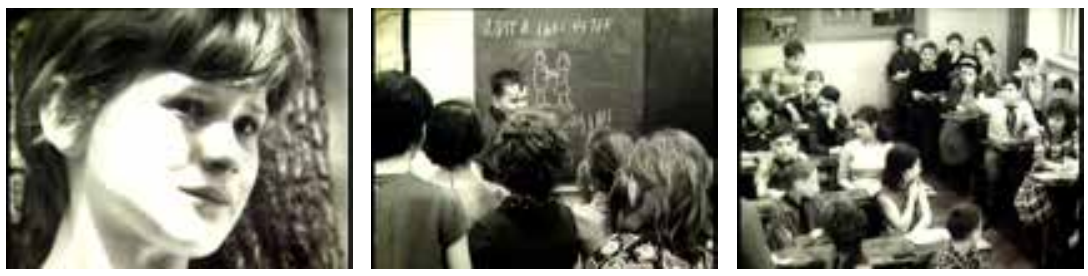

7.1. Three stills from Sagst du's deinem Kinde? ('Will you tell your child?'), 1963. ๑ DEFA-Stiftung/ Günther Biedermann.

romance novels and multiple photos were exchanged among the pupils. Seventeen obscene drawings were drawn, nine love notes were written. What's behind all of this?' In the classroom, a teacher asks her class how many pupils have spoken about the topic of today's lesson with their parents. Voice-over: 'Studies conducted at various schools have shown that only 4 per cent of pupils aged twelve to thirteen have spoken with their parents about relations between man and woman and the difficulties that go along with them. Out of 1,00o pupils 40 , out of 100 only 4 , in this class only one.' One boy raises his hand (Figure 7.1).

Voice-over: 'What do parents have to say about this?' In a parent-teacher association meeting, mothers discuss their experiences: insecurity on their part, reticence on the part of their children. It is not only the parents who are confronted with 'this problem', states one father, the school shares responsibility in the matter. Clearing his throat, he refers to biology lessons and examples from the animal kingdom. A discussion ensues. Anita's mother says: 'Yes, but the type of education we're talking about will make our children curious and then they'll just be on the lookout for indecent things everywhere they go.' A father counters: 'This sort of education can't be over and done with in a single talk. I mean, it's a process sort of thing. Education is always like that, from the very beginning.' He continues that he and his wife always answer their son's questions honestly and openly, qualifying: 'Nevertheless, I must be open and honest with you, too: That thing, it's still a bit difficult for me too.' Other mothers claim that their children still play and don't yet 'experience sexual urges', that the topic is a burden, and that

$1 \quad$ 'Jeden Tag dasselbe Theater.', 'Verstehst Du das?', 'Anita liebt Peter', 'In diesem Klassenzimmer sitzen 11- bis 12- jährige Jungen und Mädchen. Im letzten Monat gingen hier drei vulgäre Liebesromane und mehrere Fotoserien von Hand zu Hand. Siebzehn obszöne Zeichnungen wurden angefertigt und neun sogenannte Liebeszettel geschrieben. Woran liegt das?', 'Untersuchungen an verschiedenen Schulen ergaben: nur 4 Prozent der Schüler des 12. und 13. Lebensjahres sind von ihren Eltern über die Beziehungen zwischen Mann und Frau den damit zusammenhängenden Problemen aufgeklärt worden. Von 1.000 Schülern 40, von 100 4, in dieser Klasse einer.' 

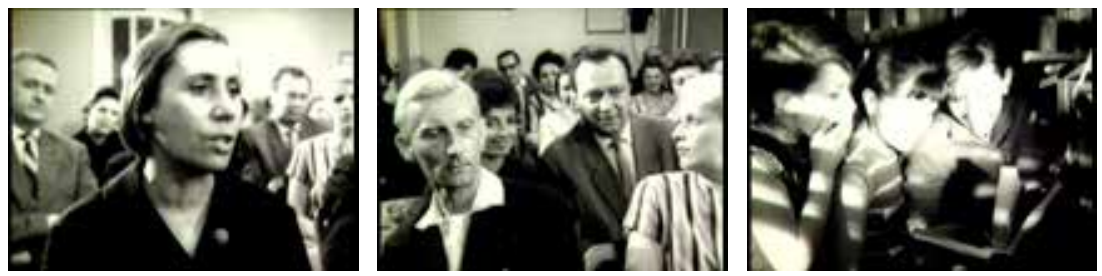

7.2. Three stills from Sagst du's deinem Kinde? ('Will you tell your child?'), 1963. @ DEFA-Stiftung/ Günther Biedermann

it can wait, because there's still 'plenty of time'. Voice-over: 'Whoever still thinks in this way underestimates the development of their children and thus their own responsibilities as parents.' ${ }^{2}$ (Figure 7.2) [...]

Voice-over: 'Educators must be conscious of children's enthusiastic search for role models, but they must also work discreetly to guide this search.' Shot on Peter, who is reading the book Vom Leben erzogen ('Brought up by life'). Voice-over: 'Above all, however, children should see their own mother and father as the role models most worthy of imitating. Even in the minutiae of everyday life.' The boy's mother brings dinner into the living room. The father warmly greets her and puts a coat on his wife's shoulders. The mother thanks him and gives him a kiss while the boy watches. Voice-over: 'Later on in life, such observations will help determine Peter's own behaviour.'3 [...]

Peter puts a coat on Anita's shoulders as they stand on the lake shore during a field trip. Voice-over: 'For Peter, what his father does is a matter of course. But what Anita also perceives as a matter of course is not seen by her parents in the same way.' At home, Anita's father makes a patronizing comment about his daughter brushing her hair. Her mother says that 'it's not right' that Anita and Peter are always together. When checking his daughter's homework, Anita's father finds a letter from Peter. The father reads sections of the letter to his wife, saying to Anita: 'This is the most ridiculous thing I've ever seen. At your age, it's just plain silly.' Anita asks

2 'Was sagen die Eltern dazu?','Nun, wieso, Aufklärung, wie die hier verlangt wird, da werden die Kinder neugierig und sehen überall bloß was Unanständiges.', 'Diese Aufklärung, die ist doch nicht mit einem Gespräch beendet. Das ist doch ein, naja ich möchte sage, ein Prozess. Das ist Erziehungsarbeit von klein auf., 'Allerdings muss ich auch offen und ehrlich sagen: Das letzte, naja, das fällt mir auch noch sehr schwer.', 'nicht geschlechtlich empfinde', 'Wer heute noch so denkt, unterschätzt den Reifegrad seiner Kinder, ebenso wie seine Erziehungsaufgaben.'

3 'Das ständige Suchen nach Vorbildern, das alle so begeisterungsfähig macht, muss von allen Erziehern bewusst, aber unaufdringlich gelenkt werden.', 'Das nachahmenswerteste Vorbild jedoch, sollten Vater und Mutter selbst sein. Auch in den alltäglichsten Kleinigkeiten.', 'Diese und ähnliche Beobachtungen werden später Peters eigenes Handeln bestimmen.' 

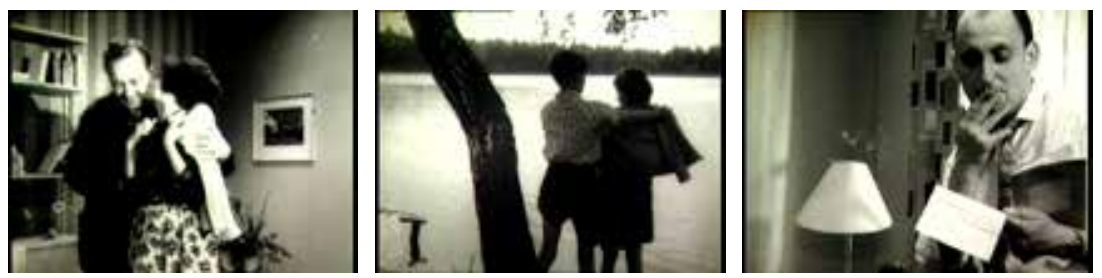

7.3. Three stills from Sagst du's deinem Kinde? ('Will you tell your child?'), 1963. @ DEFA-Stiftung/ Günther Biedermann

to have the letter back. Her father answers: 'Of course, have it framed.' He tears up the letter and throws the pieces in the trash. Voice-over: 'Does Anita's father understand the way this bitter irony hurts her? He destroys the most important thing by being so bitterly ironic: Her trust. ${ }^{4}$ Anita stares at him and leaves (Figure 7.3).

These scenes are taken from Götz Oelschlägel's film Sagst du's deinem Kinde? ('Will you tell your child?'), produced and screened in the German Democratic Republic (GDR) in 1963. The film is the first in a series of four films called Beziehungen zwischen Jungen und Mädchen ('Relations between boys and girls'), which deals with issues of sex education. Shortly thereafter, the second film, Weilich kein Kind mehr bin ('Because I'm no longer a child'), was released; in 1964, the third, titled Partner was released; and, in 1965, the fourth with the title Keine Scheu vor heiklen Fragen ('Don't be shy with delicate questions') was released. In March 1965, Oelschlägel was awarded with the prestigious Art Prize of the GDR (Kunstpreis) for these films, and the first two in particular. ${ }^{5}$

These so-called 'popular science films', released by the Deutsche Film AG (DEFA) Production Studios, belong to the health education film genre developed in Europe and the United States beginning in the $1910 .^{6}$ Over the run of their history, sex education was a central topic of these films, but it was not the only one. Usually commissioned by public-health organizations or ministries of health, the aim of these films was to inform and warn the public about health dangers and to train them to practise good health habits.

4 'Was sein Vater tut, ist auch für Peter so gut wie selbstverständlich. Doch was Anita als selbstverständlich erscheint, ist es keineswegs für ihre Eltern.', 'nicht gerne sieht [...] es sich nicht schickt', 'Alberner geht es wohl nicht mehr. In Deinem Alter, das ist doch geradezu lächerlich.', 'Selbstverständlich, lass ihn dir doch einrahmen.', 'Ob der Vater ahnt, was er mit dieser verletzenden Ironie in ihr zerstört? Das wichtigste. Ihr Vertrauen.'

5 Jahn, 'Partner'; 'Kunstpreisträger 1965'.

6 For the historical development of these films, see, for example, Bonah et al., Health Education Films; Bonah and Laukötter, 'Moving Pictures and Medicine'. 
In the GDR, DEFA Studios and the Hygiene Museum in Dresden were the primary producers and distributors of such films.

Throughout the series Beziehungen zwischen Jungen und Mädchen, the director Oelschlägel defends an open approach to questions about sexuality and promotes a new way of discussing them. While the film Partner thematized issues of intimacy among adults, the other three films focussed on a younger age group. The first film (along with parts of the fourth) was a sex education film addressed to adolescents aged eleven to twelve, and the second film, Weil ich kein Kind mehr bin, targeted teens aged thirteen to sixteen. The films depict everyday scenes in the lives of adolescents, taking up a pedagogical approach to the issues of 'relations between boys and girls'. Thus, these films deal with questions of so-called puberty.

In the run of the 2oth century, more and more significance was placed on this phase of development in the life of human beings. The establishment of paediatrics as a discipline turned the physical, mental, and emotional development of young people into an object of medical science and treatment. Interest in this phase of development was also spurred by the newly developing fields of pedagogy and psychology. ${ }^{7}$ Although there were diverging developments and opinions on the topic throughout the 2oth century, the claim can be made that, through the post-war period, pubescent youth were viewed as a cohort group who were all in a constant state of learning. This, combined with their limited life experience, made it imperative that they receive special guidance and be protected from harmful influence, a thesis confirmed by the scene from Sagst du's deinem Kinde? cited in the introduction.

Shown in different formats - from cinema to television - in a variety of settings, the chapter outlines the role these films played in discourses on sex education in the GDR, which, for their part, were highly influenced by psychology and pedagogy. The article will argue that these films not only served the pedagogical function of teaching viewers about sexuality, but also aimed to (re)produce the ideal of the 'new man' for a newly emerging socialist society that was to be founded on a new way of educating emotions. Since the education of youth was regarded as a key issue for the construction of new selves, the medium of film, with its special attractiveness for the younger generation, can be viewed as an instrument for forming new subjectivities.

In a close reading of the narrative strategies used in these films, and especially those of Sagst du's deinem Kinde?, this chapter will explain how they tried to help parents and educators navigate the difficulties of their 
child's or pupils' puberty. Based on an aesthetics designed by the director to help create a 'socialist consciousness', the film's pedagogical message puts the significance of feelings centre stage. In that sense, as the following analysis will show, the films target less the physical body as the topic to be discussed and the object to be worked on and changed. Thus, Oelschlägel did not construct the body as a form of capital to be bargained with (as those in the East thought was characteristic of the West). Instead, he focussed on the right management of emotions as the starting point and driving force for bringing new subjectivities into being. Viewed through the lens of Pierre Bourdieu's concept of different capitals, for Oelschlägel, feelings were the currency most adequate to describe the individual's position in a socialist society.

Moreover, this chapter will analyse the particular use of various film techniques to educate the emotions in this fashion. Framed in an educational and scientific setting, the films plead for parents to foster feelings such as trust, empathy, and love for one's child. Thus, the chapter will argue that the films go beyond showing parents the 'right way' to raise their child, by inviting the audience to mimic the film's emotional suggestions. In that sense, the film adopts a performative role, seeking not only to depict action, but also to effectuate it with the ultimate aim of producing socialist subjects.

\section{Sex Education in East (and West) Germany}

The history of sex education in the GDR is strongly related to its counterpart in West Germany. This is especially true for the 1950s and 196os, when East German health educators treated developments in the West as examples of how not to do things. At the same time, in both East and West, ideas about sexuality and sex education underwent a number of diverse, sometimes contradictory changes. Historians have demonstrated that the move from a conservative view of sexuality in the early years of West Germany to a more liberal approach in the period around 1968 was more complex than this linear narrative might lead one to believe. Just as well, multiple case studies have been published that refute Dagmar Herzog's claim that, in the GDR - in contrast to West Germany — sexuality was not treated as an aspect of grappling with the legacy of Nazism. ${ }^{8}$ From a broader perspective, one could argue that, despite their fundamental differences, both West Germany 
and the GDR oscillated between periods of reform and modernization, on the one hand, and periods of conservative regression, on the other. ${ }^{9}$

In the West, the shift towards a more progressive approach to sexuality found expression in various cultural phenomena: the success of Beate Uhse's sex shops; advice literature such as Oswalt Kolle's 1967 book Dein Mann, das unbekannte Wesen ('Your Husband, That Mysterious Being') and Günter Amendt's 1970 bestseller Sexfront ('Sexfront'); and in popular films like Kolle's 1968 blockbuster Das Wunder der Liebe: Sexualität in der Ehe ('The Miracle of Love: Sexuality in Wedlock'). Even the film series Schulmädchen-Report ('Schoolgirl Report') screened from 1970 to 1980 - a mixture of sex education film and soft porn-enjoyed success. ${ }^{10}$ These works tested the limits of speech about and depictions of sex in a new way. ${ }^{11}$ They were popular, but also controversial, leading to protests such as the petition movement 'Clean Movie Screen' (Saubere Leinwand) as well as demonstrations in front of cinemas. Moreover, as Franz X. Eder has argued, the individual's sexual lust advanced to a duty for the individual self-management. In a capitalist environment, sexual issues developed into a separate area of life, in which not only the sexual appetite had to be fed but in which new consumerist desires were also created: It took up Fordist notions of more work and more (sexual) experience, in which the body was conceived of as a new form of capital. $^{12}$

According to Mark Fenemore, the GDR underwent a shift in attitudes towards sexuality in the mid 1950s. This shift was partially due to the fact that Erich Honecker had withdrawn from youth politics, but was instead driven by Walter Ulbricht's speech at the Fifth Parliament of the Free German Youth (FDJ) on 26 May $1955 .{ }^{13}$ In his speech, Ulbricht called upon the daily paper Junge Welt ('Young world') to publish articles addressing topics related to sexuality on the grounds that they were relevant for young people. ${ }^{14}$ Alongside Junge Welt, many other papers followed Ulbricht's advice by publishing articles on sexuality with titles like: 'Vor einer ernsten Frage: Wer spricht mit wem über die Liebe?' ('A serious question: Who speaks with whom about love?') ${ }^{15}$ or 'Eine ältere Frau heiraten?' ('Marrying an older woman?'). ${ }^{16}$ 
Junge Welt also published articles like 'Ein Buch über Liebe' ('A book about love'), which discussed Rudolf Neubert's book Die Geschlechterfrage: Ein Buch für junge Menschen ('The question of sex: A book for young people'); the paper also published articles by Neubert himself. ${ }^{17}$ In 1952, Neubert, who held progressive positions on questions of sexuality, became Professor of Social Hygiene at the University of Jena. ${ }^{18}$ His publications, such as Was sage ich meinem Kinde? Einige Ratschläge für Eltern ('What Should I Tell My Child? Some Advice for Parents') and the vision of a new society that they put forth were the complete opposite of the gynaecologist Wolfgang Bretschneider's conservative ideas. ${ }^{19}$ In his books intended for a popular audience, among them Sexuell aufklären, rechtzeitig und richtig ('Sex Education Right and On Time'), ${ }^{20}$ Bretschneider thematized parents' anxieties about discussing procreation with their children, argued against masturbation, and made a plea for abstinence. ${ }^{21}$ The discourse of the 1950s and 1960 os was not only concentrated on parents' role in a child's upbringing, especially in their function as bearers of knowledge, but also on the role of educators. Questions about the way sex education was administered in schools, its tasks, and its functions were hotly debated. Politicians and medical doctors, but also psychologists and pedagogues played an increasingly important part in these debates. The latter also undertook scientific surveys of pupils' knowledge on the subject. Education, including sex education, was part of a wider political programme with the aim to increase the birth rate.

The films of Götz Oelschlägel taken up here belong to this period of GDR history, a period whose end coincided with the release of the last film in the series, Keine Scheu vor heiklen Fragen (1965). They thus constitute an exemplary case study that offers an interesting perspective on what could be said and shown in this period..$^{22}$ The end of this phase is marked by the 1965 Eleventh Plenum of the Central Committee of the Socialist Unity Party of Germany (SED), which introduced a new approach to youth culture and cultural politics in general. ${ }^{23}$ Alongside banning many books and plays, as

17 'Ein Buch über Liebe'; Neubert, Die Geschlechterfrage.

18 In the Weimar Republic, Neubert was a researcher and, occasionally, travelling salesman for the Hygiene Museum in Dresden, which he led for a short time after the war. He was forced to step down due to his membership in the NSDAP, but, shortly thereafter, was able to take up a position as a professor in Jena. See Fenemore, 'Growing Pains', pp. 74-75.

19 Neubert, Was sage ich.

20 Bretschneider, Sexuell aufklären.

21 Fenemore, 'Growing Pains', p. 79.

22 Niemeyer and Pfeil, Der deutsche Film.

23 Agde, Kahlschlag. See also Fenemore, 'Growing Pains', p. 84. 
well as music seen as 'too Western', party officials at the congress demanded reforms in sex education. ${ }^{24}$

\section{The Audience of the Films and their Different Media Formats}

Oelschlägel's films do not only belong to this liberal period merely by virtue of their years of production. Their content directly grapples with the aforementioned debates. Thus, the films' message - that one should trustfully interact with adolescents and take their problems and questions seriously, including the 'touchy topics' - was addressed not to young people, but to parents and educators. These films were teaching tools for the generation in charge of guiding younger people. Oelschlägel explicitly discussed his intended audience in an interview: 'Parts 1 and 2 are clearly addressed to parents and educators. They warn against taboos, which are rooted in misunderstanding; the films are designed to help grown-ups foster trustworthy understanding for the problems of adolescents. ${ }^{25}$ Partner was the exception: its target audience was the 'young generation', which is to say young adults.

The films themselves make it clear that 'parents' and 'educators' are their addressees. The voice-over repeatedly emphasizes 'parents" role in raising their children. Beyond that, 'parents' always figure prominently in the individual case studies. They have discussions with their children and debates with 'educators' at parent-teacher association meetings. In the film Sagst du's deinem Kinde?, grandparents are included among the 'parents'. The episode revolving around the young girl Sigrid thematizes the role grandparents can play in educating their grandchildren about sexuality and hygiene, while also indirectly addressing the conflict between generations: Because her grandmother was unwilling to discuss the 'touchy topics', Sigrid is surprised when she has her first period (Figure 7.4).

The group 'educators' is also treated from different perspectives. In most of the scenes involving 'educators', teachers feature as the main characters, either in their interactions with pupils or in their interactions with parents at parent-teacher association meetings. In some of the scenes, however, the 'educator' group is expanded to include counsellors, psychologists, and

24 See Regina Mönch's somewhat polemical article: Mönch, 'Kontrollverlust', p. 83. See also: Schwarz, 'Vom Jahrmarktspektakel', pp. 45-46.

25 'Teil 1 und 2 wenden sich in ihrer Aussage eindeutig an Eltern und Erzieher. Sie wollen vor falsch verstandenen Tabus warnen und bei den Erwachsenen vertrauensvolles Verständnis den Heranwachsenden und ihren Problemen gegenüber wecken und fördern.'; 'Ist Liebe ein romantischer Begriff'. All translations by the author unless otherwise stated. 

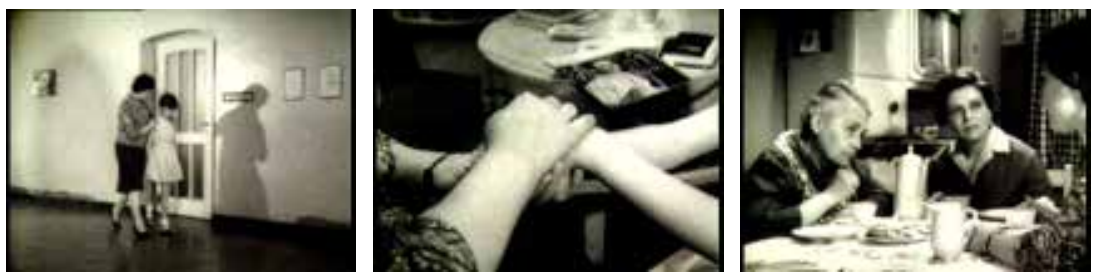

7.4. Three stills from Sagst du's deinem Kinde? ('Will you tell your child?'), 1963. @ DEFA-Stiftung/ Günther Biedermann

others. For instance, the fourth film, Keine Scheu vor heiklen Fragen, depicts a psychologist teaching sex education. ${ }^{26}$ And, in Sagst du's deinem Kinde?, the leader of the communist youth organization Freie Deutsche Jugend (FDJ) helps guide the young Sigrid through her sexual maturation. She not only educates Sigrid about 'natural things', but also advises Sigrid's mother and grandmother on how to cope with the difficulties they experience raising the young girl.

In contrast to the 'parents', the 'educators" actions always go in the right direction: They speak openly with their pupils about all their questions and do not shy away from discussing 'natural things', namely, questions about procreation. One voice-over says:

That the troop leader approaches [Sigrid] at precisely this moment is a matter of chance. But it is no matter of chance that the young girl trusts her. She earned this trust by being open in discussion and by consistently fulfilling her pedagogical duties. No good upbringing can do without such trust. ${ }^{27}$

While some parents still need to learn how to behave correctly, the educators as representational actors of the state not only know the best path of education, but are portrayed as examples worthy of imitation by the audience, inviting the parents watching the film to mimic the portrayed performance.

The audience Oelschlägel wanted to reach also determined the way the films were screened. In contrast to many health education films of the time, the films in Oelschlägel's series were not merely intended to be shown in cinemas as a part of the side show. ${ }^{28}$ In the interview cited above,

26 Cf. also Jahn, 'Keine Scheu'.

27 'Dass die Pionierleiterin gerade in diesem Augenblick [zu Sigrid, AL] kommt, ist Zufall. Kein Zufall aber ist, dass sie das Vertrauen des jungen Mädels hat. Es ist durch Offenheit und pädagogische Konsequenz erworben. Es gibt keine gute Erziehung ohne dieses Vertrauen.' 28 Bonah and Laukötter, 'Moving Pictures and Medicine'. 
Oelschlägel said: 'Like its predecessors, the film [Partner] will not be part of the official side show schedule. And I think that is right because these films are designed to promote an exchange of ideas. The most important part of their intended effect is a lively debate on the issues they address. ${ }^{29}$ Accordingly, the films (often the whole series) were shown at events for parents (parent-teacher association meetings) and pedagogues (teachers' committees, pedagogical institutes where teachers were trained, principals' conferences). ${ }^{30}$ The films were supposed to be especially interesting for 'the parent-teacher associations [Elternbeiräte], in particular the committees for pedagogical propaganda'. ${ }^{11}$ The press reported on screenings at special events like the 'Pedagogical Week' (Pädagogische Woche), an event for teachers' occupational training first held in February 1965 at the Teachers' House in Berlin. There, the first three films were screened for teachers and parentteacher associations. ${ }^{32}$ Films from Oelschlägel's series were also shown at events like the 'Seminar for Marriage Counselling', where doctors held talks on family laws, and 'Marriage Counselling from a Medical Perspective'. ${ }^{33} \mathrm{~A}$ conference on 'Problems of Sex Education' featured a viewing of the first two films. ${ }^{34}$

The films were also shown at multiple film festivals, including at the Documentary and Short Film Festival of the GDR and at a special event at the Edinburgh Film Festival. ${ }^{35}$ Keine Scheu vor heiklen Fragen was even shown at Cannes and at the Eighth Leipzig International Festival for Documentary and Short Films, where films from Canada, Iceland, Cyprus, and other 'capitalist countries' were also screened.$^{36}$ The participation in these film competitions, where Western countries competed, underlines the political value and importance of films for the GDR: They were regarded as strong currencies in the international contest on the superior form of society. The

29 'Der Film wird, wie auch seine beiden Vorgänger, nicht ins offizielle Beiprogramm gehen. Und ich finde das gut so. Denn unsere Filme sind so angelegt, daß sie zum Gedankenaustausch auffordern.'; 'Ist Liebe ein romantischer Begriff'.

30 Peschke, 'Drei Filme'; Jahn, 'Sagst Du's'. On the role of the various committees, see: Droit, Vorwärts, pp. $75^{-86 .}$

31 'Elternbeiräte, speziell die Kommissionen für pädagogische Propaganda'; Peschke, 'Drei Filme'.

32 I.G. 'Erste "Pädagogische Woche"'; Erdmann, 'Lektion und Filmabend'.

33 'Seminar für Eheberatung', 'Eheberatung in medizinischer [...] Sicht'; Ena, 'Seminar für Eheberatung'.

34 'Probleme der sexuellen Aufklärung und Erziehung'; EB, 'Beratung für Eltern'.

35 'Filme für Millionen'; 'Festivale'; Z., 'Beiträge in Edinburgh'.

36 See the advertisement in Berliner Zeitung, 21, 334 (5 December 1965), p. 4; 'Erste Gäste eingetroffen'; 'Filme aus aller Welt'; Antosch, 'Farbenreiche Filmpalette'. 
jury gave the film 'special praise'. ${ }^{37}$ In an interview, Oelschlägel states that the first two films were sold 'in Holland, Sweden, Denmark, and of course in the other socialist countries'. He also stated: 'The West German distributor Walter Leckebusch, who acquired the rights to distribute them [the first two films], also signed a pre-contract for the distribution rights to Partner at the last Documentary and Short Films Festival in Leipzig without seeing it.. ${ }^{38}$

In 1968, a year in which the decisions of the Eleventh Plenum of the Central Committee of the SED had already begun to have their effects and the 'sexual revolution' in West Germany was being taken to the streets, Keine Scheu vor heiklen Fragen and at least two of the other films were screened on GDR television in response to the dominant forms of 'filthy education'.39 Handwritten remarks on the official film board's protocols, which had to be completed before a film could receive permission to be screened, indicate that further screenings of the films were planned through the end of the 1970 and the beginning of the $1980 .^{40}$

Besides the fact that these films were put to multiple uses over a longer period of time, the different media in which they were shown is remarkable: These films were not only produced for the cinema screens in different settings (from festivals to schools), but also for television. The change in media, however, took place without any changes to the films themselves. The practice of presenting films in different formats was not limited to Oelschlägel's series, but was applied to other productions, too. ${ }^{41}$ The obvious explanation is that this was a cost-saving measure. However, Oelschlägel's series was produced on expensive $35 \mathrm{~mm}$ film material (while, in West Germany, comparable productions were produced on much cheaper $16 \mathrm{~mm}$ film material): The use of superior film stock

37 Knietzsch, 'Festival mit Niveau'; advertisement in Berliner Zeitung, 21, 334 (5 December 1965), p. 4 .

38 'nach Holland, Schweden, Dänemark und natürlich in die sozialistischen Länder', 'Der Westdeutsche Verleiher Walter Leckebusch, der sie ebenfalls ankaufte, hat z. B. auf dem letzten Dokumentar- und Kurzfilmfestival in Leipzig unbesehen einen Vorvertrag für die "Partner" abgeschlossen.'; 'Ist Liebe ein romantischer Begriff'.

39 'Keine Scheu vor heiklen Fragen'.

40 See BA Filmarchiv: DR 1-Z/4081a, Protocol No. 0308/63, 29 July 1963 (on Sagst du's deinem Kinde?); DR 1-Z/4647a, Protocol No. 0498/63, 4 December 1963 (on: Weil ich kein Kind mehr bin); 2248/2248c, Protocol No. 0519/64, 7 December 1964 (on Beziehungen zwischen Jungen und Mädchen, III. Teil); 2247c/2247, Protocol No. 0219/65, 27 August 1965 (on: Keine Scheuvor heiklen Fragen).

41 See, for example, the series Wegweiser Gesundheit, which was produced between 1974 and 1984; Schwarz, 'Vom Jahrmarktspektakel', pp. 31, 46. See also Hauptstaatsarchiv Dresden, ${ }^{36} 65^{8}$ Deutsches Hygiene-Museum Dresden, F V Bd. 2, pp. 21-46. 
implies that the quality of these productions might have been seen as more important than their cost. In the end, though, screening the films in multiple formats might be better explained if one considers that cinema and television were not regarded as fundamentally different or even different at all. At the same time television evolved into a mass medium, it also developed in the GDR of the 196os along 'ideological guidelines': TV formats, themes, and statements were under state control. ${ }^{42}$ In terms of the topic of Oelschlägel's series, one might argue then that the specific message of the series - the education of the emotions - was not viewed as pertinent for parents and teachers only, but as something that had relevance for everyone in the GDR.

\section{Film Techniques Used in the Series}

\section{The Discussion}

When the films were screened to parents, the film's producers recommended that a 'discussion' be held afterwards, 'preferably accompanied by doctors', ${ }^{43}$ a recommendation based on the assumption that parents would 'have a lot of questions. ${ }^{44}$ Sometimes, psychologists led the discussions. In the first half of the 2oth century, screenings of health education films were commonly preceded by 'scientific' presentations held by doctors. 45 This technique of rhetorically reframing the film was supposed to lead the audience to receive the film in the intended way. ${ }^{46}$ Most sources contain little information about the discussions held after screenings. We know that such discussions took place, but the insufficient source material makes it difficult to know exactly what was discussed and how the discussions (as a way of processing the viewed material) were organized. Thus, sources like Inge Gerlich's articles in the Berliner Zeitung, in which she reports on the discussions that followed screenings of films from Oelschlägel's series, are a boon for the historian. In one of her reports, Gerlich anonymizes the discussion participants, calling them 'a father' or 'a biology teacher' when 'quoting' their opinions. ${ }^{47}$ In a report on a screening of Partner, however,

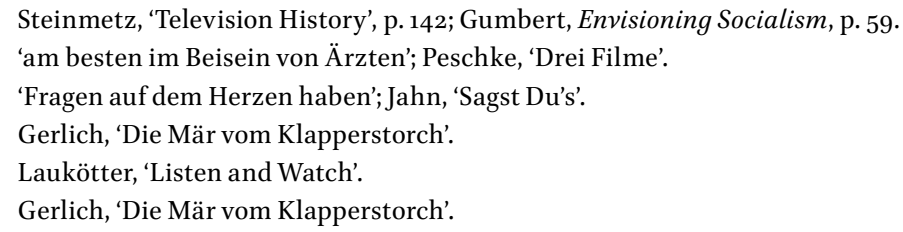


she names the experts who participated when citing their contributions to the discussion: Elfried Göldner, High Court Judge; Dr. Lotte Winter, School Psychologist, Pankow; Dr. Linda Ansorg, Associate Professor for Civil and Family Law at the Humboldt University; Dr. Bernd Bittighöfer (named without his professional background). ${ }^{48}$

The discussion was a central aspect of the films themselves as well. Talks between doctor and patient are a technique of health education films well-known in the historiography. In the films of the first half of the 2 oth century in particular, the doctor plays the role of an adviser to the patient, dominating the 'discussion' as the real-life incarnation of knowledge itself. In contrast, Oelschlägel places both on equal footing, transforming the discussion into a dialectical dialogue of statement and objection. The frequent use of such dialogues distinguishes Oelschlägel's take on the discussion from earlier health education films. The different forms of dialogue used by Oelschlägel are also exceptional: Along with the one-on-one discussion, he also depicts 'debates' between educators and parents as well as roundtable discussions like the one in the parent-teacher association meeting in the film Sagst du's deinem Kinde? Throughout the four films, discussions between child and parent/educator are depicted as the incarnation of trust and as a necessary precondition for finding a solution. Thus, Oelschlägel promoted a cooperative parent-child relationship based on trust and empathy, and the film emphasized solutions reached by consensus rather than by command.

The films themselves directly address the sociopolitical implications of these democratic interactions. Similarly, the documented discussions after the screenings reflect on them, too: A father states that there were no simple answers for the difficulties parents experienced when trying to talk to their kids about sex. Instead, he thinks it must be left to parents to find the right words: 'The truth alone decides. But unfortunately, parents don't always know the truth. [...] It is good that we are having an open discussion about these problems [...]. For a long time now, we have neglected to hold such public debates. ${ }^{49}$ Deployed in this way, the discussion is elevated to a symbol of openness and figures as the central cultural technique of a modern socialist society.

48 Gerlich, 'Den richtigen Partner'.

49 'Die Wahrheit ist es, die allein entscheidet. Leider kennen sie die Eltern manchmal selbst nicht. [...] Daß wir offen über die Probleme sprechen, [...] das ist gut. [...] Solche Auseinandersetzungen in der Öffentlichkeit haben wir für lange Zeit versäumt.'; Gerlich, 'Die Mär vom Klapperstorch'. 


\section{Narrative Contrast and Estrangement Effects}

The actions of the 'parents' structure the films' narratives. Just as well, however, the reactions of their children and the voice-over clearly classify parents' approaches as either 'right' or 'wrong': Either they are open to discussing the 'touchy topics' of sexuality with their children, or they aren't. As in many other health education films from the first half of the 2 oth century, Oelschlägel's films place the two attitudes in juxtaposition. For example, in the case of Anita's and Peter's parents referred to above, the voice-over makes a clear judgement about which approach to the adolescent's problems is the right one, namely, that of Peter's parents. ${ }^{\circ}$ While Peter's parents represent the good role model that, as the film shows, will be copied by the next generation (symbolized here by Peter), the future of Anita's development with her mistrusting parents is not further explored but left to the viewer's imagination. Contrasted with the positive example given by Peter and his parents, the negative path that her development will take is depicted as self-evident and without alternative.

In Weil ich kein Kind mehr bin, the alternatives posed by this narrative strategy are compressed into the decision that one parent has to make. A mother finds a love letter addressed to her daughter. One choice is to read it and tear it up, which would not only damage her child's trust in her, but would also force her child to lie, as everybody knows that 'the forbidden fruit is the sweetest'. The alternative is set off by a freeze-frame: The mother brings the letter to her daughter's teacher and has a discussion with him about it. The teacher's assurances that the relationship between Lilo and Bernd is 'exemplary' and 'clean' have a calming effect on the mother. He advises her to exert 'control through trust'. '1 $^{1}$

This is the only instance of such an open-ended narrative in the series. But, taken together with the extradiegetic voice-over, whose presence is consistent throughout the entire series, it is clear that the films' mimetic illusion is constantly being broken. The voice-over not only comments, corrects, or supports the screened actions, but also brings the audience into the narrative, using 'we' when making comments and offering viewers advice on how to translate the knowledge imparted by the film into their own lives. The estrangement effects deployed by Oelschlägel in his film series can be traced to Bertolt Brecht's Epic Theatre. The aim of the technique is 
to break through the mimetic illusion of the stage, thus provoking audience members to take a critical position on the actions depicted.$^{2}$ Applied to this pedagogical context, one might argue that, even though Oelschlägel invites his audience to copy the performed actions of the presented educators, he still ascribed the audience an agency to thoughtfully engage with the material presented. As he outlined in his discussions on his aesthetic approach (which will be discussed later), he thought that the viewer should feel involved as 'a fellow researcher' of the knowledge transmitted by the film. ${ }^{53}$ Moreover, by using this technique, Oelschlägel set his work in dialogue with experimental films in the 196os, which also made use of this technique in their films, to underline his artistic self-understanding and approach.

\section{The Voice of Social Sciences}

The status given to the voice-over intensifies its estranging effect. The voice comments on the characters' actions and choices from a distance and often provides additional scientific information, like the following voice-over from a scene in Sagst du's deinem Kinde?: 'Studies conducted at various schools have shown that only 4 per cent of pupils aged twelve to thirteen have spoken with their parents about relations between man and woman and the difficulties that go along with them. Out of 1,00o pupils 40, out of 100 only 4 , in this class only one. 54

The voice-over also explains the actions of the psychologist holding class in Keine Scheu vor heiklen Fragen. The psychologist's lesson deploys images from medical science, and he even tells pupils about a sex education film being screened at the local cinema. The voice-over then undergirds the psychologist's position not only by emphasizing the latter's scientific expertise, but also by positioning itself as a sort of objective observer. In other words, the extradiegetic voice is depicted as the voice of science itself. The scientific framework not only plays a significant role in the films themselves, but was also instrumental in their production and distribution. Gerhard Witzlack from the Psychology Division of the German Institute for Pedagogy served as a technical adviser on the set of all the films in the series. Additionally, the pedagogue Sigrid Hauptvogel served as a technical

52 Walsh, Brechtian Aspect. Cf. also Wulff, 'Verfremdungseffekt'.

53 'Mitforscher'; Oelschlägel, 'Warum', p. 248.

54 'Untersuchungen an verschiedenen Schulen ergaben: nur 4 Prozent der Schüler des 12. und 13. Lebensjahres sind von ihren Eltern über die Beziehungen zwischen Mann und Frau den damit zusammenhängenden Problemen aufgeklärt worden. Von 1.00o Schülern 40, von 100 4, in dieser Klasse einer.' 
adviser for the first three films, Heinz Grassel replacing her for the fourth. Grassel had published in the field and argued that sex education should be taught in public schools. ${ }^{55}$ Employing academic advisers to ensure the correctness of the scientific knowledge propagated was common for such films. But, in the first half of the 2oth century, this role was usually filled by medical doctors. The expansive use of psychologists and pedagogues was a new phenomenon, which can be explained by the fact that, in the post-war years, psychology and pedagogy were increasingly concerned with the practical application of their research.

Witzlack also wrote the 'Pamphlets for Educational Films' ('Beiheft zum Lehrerbildungsfilm') that were to be read by the professionals screening Oelschlägel's films and running the post-screening discussions. In these pamphlets, Witzlack explained the films' contents and intentions and discussed the various ways the screenings could be organized. Witzlack explicitly comments on the ways these pamphlets were supposed to be used: 'For training teachers in the fields of psychology and pedagogy and for pedagogical propaganda. ${ }^{5}$

As the films themselves make the scientific nature of their treatment of the topic explicit, it seems that the scientific knowledge referred to would be made explicit as well. However, the opposite is the case. Although the films make a plea for parents and educators to be open to discussing 'touchy topics', they neither pose concrete questions about the act of sex, contraception, etc., nor do they offer any concrete answers. In the films and in the reportage on their screenings, terms like sexuality, sex, procreation, and sexual organs are not mentioned at all. The only exception is in Keine Scheu vor heiklen Fragen, in which a psychologist refers to a woman's vagina when discussing the female body. In another scene, during the positive father-son talk, words like 'bodily unification' and 'phallus' are used. Otherwise, the films speak of 'the problem' when addressing sex or sexual contact. ${ }^{57}$ The reportage on the films is similar. One report discusses a 'biology teacher' who seeks to improve adolescents' knowledge about the 'problems of how people are made'. ${ }^{8}$ In one of the discussions cited, Linda Ansorg, the law expert from Humboldt University, speaks of 'society's responsibility'. And Bernd Bittighöfer from the SED Central Committee's Institute for Social

55 Grassel and Heilbock, Erziehung zur künftigen Liebe.

56 'Für die Lehrerausbildung und Lehrerweiterbildung in den Fächern Psychologie und Pädagogik sowie für die pädagogische Propaganda'; Witzlack, Beiheft zum Lehrerbildungsfilm.

57 'körperliche Vereinigung', 'männliches Glied', 'Problem'.

$5^{8}$ 'Probleme der Menschwerdung'; Gerlich, 'Die Mär vom Klapperstorch'. 
Sciences speaks of the 'failure of social forces' when discussing the parents' false approaches depicted in the films. Details on questions of sexuality and procreation are wholly absent. ${ }^{59}$ The same is true for the visualization of any forms of sexuality and questions of reproduction. While in the first half of the 2oth century health education films were called 'hybrids' because they combined fictional stories with scientifically informed visual 'facts', Oelschlägel left out any form of precise visualization of these issues: We only see short kisses. In other words, the proclaimed openness to talk and visualize sexuality and reproduction had its limits and price. Thus, the films stress more the educative than the sexual-information aspects. The teaching on sexuality blurs into a teaching on teaching.

\section{The Depiction of Emotions in the Series}

The way knowledge about sexuality is presented in the films has an asymmetrical relation to the way emotions are thematized. While the presentation of sexual knowledge is filled with gaps, emotions are discussed intensively. The films argue for trust, understanding, empathy, for taking the feelings of adolescents seriously, and for 'true' love. Interestingly, the camera often takes up the perspective of the adolescents in a style reminiscent of cinéma vérité. ${ }^{60}$ This technique was also used, for example, in French (amateur and television) films on sex education; ${ }^{61}$ however, there is no way to verify whether there were close connections and exchanges between Oelschlägel and these French directors. ${ }^{62}$ Yet, he might have been exposed to these documentary trends on the basis of his (and his film's) participation in film festivals with international involvement.

Additionally, the films feature recordings of real-life adolescents' conversations to fill out the feelings and thoughts of the fictional adolescent characters. Gender-specific differences are also marked: The boys are depicted as sexually active, whereas the girls are depicted as more reserved. Ria's attempts to overcome her coyness in Weil ich kein Kind mehr bin are the only exception, but her behaviour is portrayed as stemming from her vanity and thus as something to be avoided. In that sense, the films mirror

59 'Verantwortung der Gesellschaft', 'Die gesellschaftlichen Kräfte haben in diesem Fall versagt.'; Gerlich, 'Den richtigen Partner'.

6 o Winkler, 'Biology, Morality and Gender'.

61 See the contribution by Christian Bonah in this volume.

62 Cinéma vérité techniques also gained attention in US televised medical dramas in the late 1960 s to prove film's authenticity. See: Ostherr, Medical Visions, pp. 152-189. 
not only contemporary gender roles, but they also express how they are emotionally evaluated.

Actions like writing 'Anita loves Peter' on the blackboard in Sagst du's deinem Kinde? are not condemned, but are treated as 'play' or as adolescents 'putting their feet in the water'. The films depict the adolescents as being in a sort of in-between situation, no longer children, but not yet adults. For this reason, they have to receive guidance from educators, the school, parents, pedagogues, and psychologists when trying to deal with their own emotions. The films suggest that managing emotions is the only way to ensure that adolescents make it through puberty without getting into family and school conflicts. Puberty is thus constructed as a process of transformation that needs guidance from socialist methods of education, including openness, trust, and 'independence and responsibility for oneself'. ${ }^{63}$ The closing sequence of Sagst du's deinem Kinde? makes the social dimension of this education of adolescents explicit. The voice-over states: 'We know we have done a good job raising our children when their desire to be useful for others has become an essential part of their character. ${ }^{64}$ In other words, adolescents not only go through a biological process, transitioning from life as a child to life as an adult, but also undergo a political transformation, becoming members of a new socialist society.

Negatively assessed emotions are also depicted in the films, and are always attributed to the parents. For example, in Weil ich kein Kind mehr bin, the voice-over says Ria's mother 'raised her to be vain'. The voice-over also accuses another child's parents of having 'blind trust' in their child as a consequence of their self-centredness. ${ }^{6}{ }^{5}$ Sagst du's deinem Kinde? and Keine Scheu vor heiklen Fragen both treat a lack of trust and understanding, coupled with strictness and punishment, as counterproductive in the process of education. Moreover, the inclusion of interviews with adolescents living in youth homes in Keine Scheu vor heiklen Fragen underscores the consequences of parents' failure to provide their children with a good upbringing. The adolescents from youth homes talk about their traumatic childhood experiences, explaining how they were beaten, attacked with a kitchen knife, or abandoned by their parents. And they inform viewers about the after-effects of their experiences, like one adolescent who explicitly states that, because of her experiences, she doesn't think she would ever have children of her own.

63 'Selbständigkeit und Eigenverantwortung'; Witzlack, Beiheft zum Lehrerbildungsfilm, p. 19.

64 'Wir haben unsere Kinder dann gut erzogen, wenn ihnen das Gefühl, für andere nützlich sein zu wollen, zum Charakterbedürfnis geworden ist.'

65 'herangezüchtete falsche Eitelkeit', 'blinde Vertrauensseligkeit'. 
While earlier sex education films emphasized the transmission of knowledge and treated the discussion of emotions as just another mode of communicating it, Oelschlägel's films differ because they place primacy on education about emotions themselves. As we have seen, the 'emotional education' articulated in Oelschlägel's films not only forwards the notion that adolescents must be guided by educators when dealing with their emotions. Just as well, the emotions of adults (that is, the intended audience of the films) also have to be educated.

\section{Emotions within Oelschlägel's Aesthetics}

In his films, Götz Oelschlägel emphasized the important sociopolitical role of emotions in the process of education, and in sex education in particular. Beyond that, he also thought emotions were an important political factor, an idea that informed how he directed his films and addressed his audience. His theoretical writings on film in the GDR, including 'popular science films', demonstrate this.

In an article published in 1961, Oelschlägel posed the question: 'Why are our films so boring?' ('Warum sind unsere Filme langweilig?') ${ }^{66}$ The question was occasioned by the fact that the films most praised in the GDR enjoyed no resonance at international film festivals. Oelschlägel was not convinced by the argument that the films' contents were 'scientifically founded and socially useful' and that it was simply the form of the films that were 'uninteresting, uninspired, deficient', because, for him, following the 'theses of Marxist-Leninist aesthetics', form and content could not be separated, but were necessarily fused in a 'dialectical unity'. A film's underlying idea, concept, and mode of presentation were thus not issues of form, but issues of content. For him, content was 'a form of selection, ideologically-artistically conceived material, not simply material that speaks for itself' ${ }^{67}$ This 'aesthetic, concept-based character of content' had to be carried by an 'artistic idea': 'Without an artistic idea, a film cannot become a work of art. Without an artistic idea, a popular-science film will not be convincing. ${ }^{68}$ Oelschlägel

66 Oelschlägel, 'Warum'; Winkler, 'Biology, Morality and Gender'.

67 'wissenschaftlich einwandfrei und gesellschaftlich nutzbringend', 'mangelhaft, einfallslos, uninteressant', 'These der marxistisch-leninistischen Ästhetik', 'dialektische Einheit', 'gestaltete Auswahl, ist ideologisch-künstlerisch konzipierter Stoff, nicht Stoff mit Aussage schlechthin'; Oelschlägel, 'Warum', p. 247.

68 'ästhetisch-konzeptionelle Charakter des Inhalts', 'künstlerische Idee', 'Ohne künstlerische Idee wird ein Spielfilm kein Kunstwerk. Ohne künstlerische Idee wird ein populärwissenschaftlicher Film keine Überzeugungskraft haben.'; Oelschlägel, 'Warum', p. 247. 
did not consider popular-science films works of art, since they were not concerned with the 'knowledge of man', but rather with 'transmitting objective laws'. Nevertheless, he thought that films of this genre also needed to have an artistic idea in order to be effective, and that previous films of the genre had worked according to a different principle. ${ }^{69}$ In them, the topic addressed was the content, the didactic element informed the dramaturgy, and the 'message was the principle of their form'. For this reason, the films were overburdened with didactic considerations, and, as a result, they were ineffective. Accordingly, Oelschlägel continues: 'In popular science films, the artistic idea is the key to viewing the dramaturgic staging of the material as the content itself. It is the conditio sine qua non for the effectivity of the intended message. The essence of the artistic idea is always emotional..$^{70}$

In other words, for Oelschlägel, transmitting the ideals of socialist education through film was contingent upon the films' form being guided by an emotionally based artistic idea. He was thus not interested in amusing his audience or making them laugh, but in evoking feelings of 'creative pleasure, even happiness and pride' in the viewer watching objective scenes of scientific research..$^{71}$ As mentioned above, Oelschlägel's specific understanding of socialist ideals implied that the viewer should feel involved as 'a fellow researcher' of the knowledge being transmitted by the film. Thus, he asked of each and every film: 'Which artistic idea leads our creative, interested, knowledge-hungry viewer to understand the truth of the topic addressed? Which means are suited to create suspense, wake interest, and evoke joy in the production of novel, relevant, and legitimate connections?'?2

Additionally, Oelschlägel stated that the 'author's ethical and scientific drive to communicate' manifests itself through the artistic idea as 'action', claiming that it takes an artistic idea to activate 'ideological wisdom'. He

69 'Erkenntnis des Menschen', 'Kenntnisvermittlung objektiver Gesetzmäßigkeiten'; Oelschlägel, 'Warum', p. 248.

70 'daß die Aussage zum Prinzip der Gestaltung erklärt wird', 'Die künstlerische Idee beim populärwissenschaftlichen Film ist der Schlüssel zur dramatischen Konzipierung des Stoffes als Inhalt, ist die unabdingbare Voraussetzung für die Wirksamkeit der beabsichtigten Aussage. Das Wesen der künstlerischen Idee ist immer emotional.'; Oelschlägel, 'Warum', p. 248.

71 On pleasure in socialist states, see Crowley and Reid, 'Introduction'.

72 'schöpferisches Vergnügen, ja Glück und Stolz', 'Mitforscher', 'Welche künstlerische Idee führt den Zuschauer, den interessierten, von plötzlichem Wissensdurst gepackten, von schöpferischem Vergnügen erfaßten Zuschauer zur Erkenntnis der Wahrheit unseres Themas? Welche Mittel sind geeignet, Spannung zu erzeugen, Interesse zu wecken, Spaß empfinden zu lassen beim Auffinden neuartiger, großer gesetzmäßiger Zusammenhänge?'; Oelschlägel, 'Warum', p. 248. 
concluded that the sooner directors recognize this drive to communicate as a 'social responsibility', the sooner their films would have an active effect on the 'development of socialist consciousness'.73

\section{Conclusion}

The artistic ideas Götz Oelschlägel had in mind when producing his series Beziehungen zwischen Jungen und Mädchen cannot be easily reconstructed. However, this article has sought to elucidate the wide spectrum of techniques he deployed - such as discussion, narrative contrasts, estrangement effects, voice-overs as the voice of science, and the depiction of emotions - and their various functions within his films. These techniques served to 'create suspense', 'wake interest', and 'evoke joy' in adults responsible for guiding their adolescents through puberty.

The analysis also demonstrated that Oelschlägel considered puberty and the questions of sexuality and procreation bound up with it to be a special cinematic object. Although the films take their impetus from a biological process, the cinematic depiction of the difficulties of adolescence were taken as an occasion for making political statements about the education of the 'socialist subject'. At the same time, the topic made it possible for Oelschlägel to address his visions about socialist education to two different audiences: adolescents as well as their parents and educators. From this perspective, Oelschlägel's films can also be read as a form of instruction for the development of 'socialist consciousness'. It is certainly remarkable that Oelschlägel's definition of social responsibility was less guided by the concern to simply transmit knowledge and more guided by a concern to help shape viewers' emotions. This shows the extent to which emotions were seen as a key to health education at that time. Thus, the suggestive potential of films to change people's emotions by depicting emotions to be imitated has a political and performative dimension that needs to be taken into account, and not only by those working in film history.

As stated at the beginning, the series' last film, Keine Scheu vor heiklen Fragen, marked the end of a liberal era in the history of the GDR. In the decades that followed, Oelschlägel's call for a more open approach to politics, experimentation in film, and a filmic engagement to foster feelings such

73 'das ethische und wissenschaftliche Mitteilungsbedürfnis der Autoren', 'ideologische Weisheit', 'gesellschaftliche Verantwortlichkeit', 'Entwicklungsprozeß sozialistischen Bewußtseins'; Oelschlägel, 'Warum', p. 249. 
as trust, empathy, and love for one's child was not answered. In contrast, older didactic ideas underwent a renaissance. Götz Oelschlägel, who died on 29 May 1969, likely would have resented this, as: 'One feels so much in these times!'74

\section{Works Cited}

\section{Films, Television Programmes, and Recordings}

Keine Scheu vor heiklen Fragen, directed by Götz Oelschlägel, DEFA, 1965.

Partner, directed by Götz Oelschlägel, DEFA, 1965 .

Sagst du's deinem Kinde?, directed by Götz Oelschlägel, DEFA, 1963.

Weil ich kein Kind mehr bin, directed by Götz Oelschlägel, DEFA, 1964.

\section{Books and Articles}

Agde, Günter, ed., Kahlschlag: Das 11. Plenum des ZK der SED 1965: Studien und Dokumente (Berlin: Aufbau-Taschenbuch-Verlag, 1991).

Antosch, Georg, 'Farbenreiche Filmpalette: Erste Eindrücke vom VIII. Dokumentarund Kurzfilmfestival in Leipzig', Neue Zeit, 20, 270 (18 November 1965), p. 3 .

Bauer, Heinz, 'Eine ältere Frau heiraten?', Junge Welt, 10, 158 (7/8 July 1956), p. 5 .

Bonah, Christian, David Cantor, and Anja Laukötter, eds., Health Education Films in the Twentieth Century (Rochester: University of Rochester Press, 2018).

Bonah, Christian, and Anja Laukötter, 'Moving Pictures and Medicine in the First Half of the 2oth Century: Some Notes on International Historical Developments and the Potential of Medical Film Research', Gesnerus: Swiss Journal of the History of Medicine and Sciences 66, 1 (2009), pp. 121-145.

Bretschneider, Wolfgang, Sexuell aufklären, rechtzeitig und richtig: Ein Ratgeber für sexuelle Erziehung (Leipzig: Urania-Verlag, 1956).

Crowley, David, and Susan E. Reid, 'Introduction: Pleasures in Socialism?', in Pleasures in Socialism: Leisure and Luxury in the Eastern Bloc, ed. by David Crowley and Susan E. Reid (Evanston, IL: Northwestern University Press, 2010), pp. $3-51$.

Droit, Emmanuelle, Vorwärts zum neuen Menschen? Die sozialistische Erziehung (1949-1989), trans. by Michael Esch (Cologne: Böhlau, 2014)

EB, 'Beratung für Eltern', Berliner Zeitung, 22, 12 (12 January 1966), p. 12.

74 'Man fühlt so viel in dieser Zeit!' This statement is a quote from Oelschlägel's series Relations between Boys and Girls. 
Eder, Franz X., 'Das Sexuelle beschreiben, zeigen und aufführen: Mediale Strategien im deutschsprachigen Sexualdiskurs von 1945 bis Anfang der siebziger Jahre', in Fragen Sie Dr. Sex! Ratgeberkommunikation und die mediale Konstruktion des Sexuellen, ed. by Peter-Paul Bänziger, Stefanie Duttweiler, Philipp Sarasin, and Annika Wellmann (Berlin: Suhrkamp, 2010), pp. 94-122.

'Ein Buch über Liebe: Prof. Dr. Neubert antwortet auf Fragen junger Menschen', Junge Welt, 10, 158 (7/8 July 1956), p. 5 .

Ena, 'Seminar für Eheberatung', Neue Zeit, 20, 88 (16 April 1966), p. 5 .

Erdmann, Horst, 'Lektion und Filmabend', Neues Deutschland, 20, 42 (11 February 1965$),$ p. 5 .

'Erste Gäste eingetroffen', Neues Deutschland, 20, 311 (11 November 1965), p. 4.

Fenemore, Mark, 'The Growing Pains of Sex Education in the German Democratic Republic (GDR), 1945-69', in Shaping Sexual Knowledge: A Cultural History of Sex Education in Twentieth Century Europe, ed. by Lutz D. H. Sauerteig and Roger Davidson (London: Routledge, 2009), pp. 71-90.

Fenemore, Mark, Sex, Thugs and Rock 'n' Roll: Teenage Rebels in Cold-War East Germany (New York: Berghahn, 2007).

'Festivale', Neues Deutschland, 21, 236 (28 August 1966), p. 8.

'Filme aus aller Welt: Zur VIII. Internationalen Dokumentar- und Kurzfilmwoche', Berliner Zeitung, 21, 314 (14 November 1965), p. 6.

'Filme für Millionen: Woche des Kurz- und Dokumentarfilms vom 2. bis 15. Oktober', Neues Deutschland, 19, 272 (2 October 1964), p. 4.

Gerlich, Inge, 'Den richtigen Partner gewählt?', Berliner Zeitung, 21, 188 (11 July 1965), p. Beilage 8 [16].

Gerlich, Inge, 'Die Mär vom Klapperstorch oder ...', Berliner Zeitung, 20, 128 (10 May 1964), p. Beilage 3 [11].

Grassel, Heinz, and Klaus Heilbock, Erziehung zur künftigen Liebe (Berlin: Volk und Wissen, 1958).

Gumbert, Heather L., Envisioning Socialism: Television and the Cold War in the German Democratic Republic (Ann Arbor: University of Michigan Press, 2014).

Hall, G. Stanley, Adolescence: Its Psychology and its Relations to Physiology, Anthropology, Sociology, Sex, Crime, Religion and Education, vols. 1 and 2 (New York: Appleton, 1919).

Herzog, Dagmar, “Das späte Menschenrecht”: Auf der Suche nach einer nachfaschistischen Sexualmoral', in Demokratie im Schatten der Gewalt: Geschichten des Privaten im deutschen Nachkrieg, ed. by Daniel Fulda, Dagmar Herzog, Stefan L. Hoffmann, and Till van Rahden (Göttingen: Wallstein, 2010), pp. 201-230.

Herzog, Dagmar, Sex after Fascism: Memory and Morality in Twentieth-Century Germany (Princeton: Princeton University Press, 2005)

I.G., 'Erste “Pädagogische Woche”', Berliner Zeitung, 21, 34 (3 February 1965), p. 12. 
'Ist Liebe ein romantischer Begriff? Partner-Ein Film für junge Leute, der Diskussionen provoziert', Du und deine Zeit-Wochenendbeilage der Jungen Welt, 3 (16/17 January 1965), not paginated.

Jahn, Marianne, 'Keine Scheu vor heiklen Fragen', Elternhaus und Schule, 13, 2 (1966), p. 28.

Jahn, Marianne, 'Partner', Elternhaus und Schule, 14, 5 (1965), p. 19.

Jahn, Marianne, 'Sagst Du's deinem Kinde? DEFA-Filme zur sexuellen Erziehung: Wichtig für Lehrer und Eltern', Deutsche Lehrerzeitung, 11, 8 (21 February 1964), p. 6.

'Keine Scheu vor heiklen Fragen', Berliner Zeitung, 24, 202 (24 July 1968), p. 10.

Knietzsch, Horst, 'Festival mit Niveau: Zu einigen Filmen der VIII. Internationalen Leipziger Dokumentar- und Kurzfilmwoche', Neues Deutschland, 20, 326 (27 November 1965), p. 4.

'Kunstpreisträger 1965', Berliner Zeitung, 21, 73 (14 March 1965), p. 6.

Laukötter, Anja, 'How Films Entered the Classroom: The Sciences and the Emotional Education of Youth through Health Education Films in the United States and Germany, 1910-30', Osiris, 31, 1 (2016), pp. 181-200, doi:10.1086/688161.

Laukötter, Anja, 'Listen and Watch: The Practice of Lecturing a Film and the Epistemological Status of Sex Education Films in Germany', Gesnerus: Swiss Journal of the History of Medicine and Sciences, 1 (2015), pp. 56-76.

Laukötter, Anja, 'Politik im Kino: Eine Emotions- und Wissenschaftsgeschichte des Sexualaufklärungsfilms im 20. Jahrhundert' (Habilitation thesis, Humboldt Universität zu Berlin, 2018).

Miersch, Annette, Schulmädchen-Report:Der deutsche Sexfilm der 7oer Jahre (Berlin: Bertz, 2003).

Mönch, Regina, 'Kontrollverlust: Filme und das wirkliche Leben', in Kamera! Licht! Aktion! Filme über Körper und Gesundheit 1915-1990, ed. by Susanne Rößiger and Uta Schwarz (Dresden: Sandstein, 2011), pp. 78-84

Neubert, Rudolf, Die Geschlechterfrage: Ein Buch fürjunge Menschen (Rudolstadt: Greifenverlag, 1956).

Neubert, Rudolf, Was sage ich meinem Kinde? Einige Ratschläge für Eltern (Rudolstadt: Greifenverlag, 1961).

Niemeyer, Christin, and Ulrich Pfeil, eds., Der deutsche Film im Kalten Krieg / Cinéma allemand et guerre froid (Brussels: Lang, 2014).

Oelschlägel, Götz, 'Warum sind unsere Filme langweilig?', Deutsche Filmkunst: Zeitschrift für Theorie und Praxis des Filmschaffens, 9, 7 (1961), pp. 247-249.

Ostherr, Kirsten, Medical Visions: Producing the Patient through Film, Television and Imaging Technologies (Oxford: Oxford University Press, 2013).

Pelzer, Helmuth, 'Vor einer ernsten Frage: Wer spricht mit wem über die Liebe? Zu einem Erziehungsproblem', Junge Welt, 10 (4/5 February 1956), not paginated. 
Peschke, Norbert, 'Drei Filme suchen ihr Publikum: Zu der Filmtrilogie "Begegnung mit dem anderen Geschlecht"', Elternhaus und Schule, 13, 3 (1964), p. 16.

Schwarz, Uta, 'Vom Jahrmarktspektakel zum Aufklärungsinstrument: Gesundheitsfilme in Deutschland und der historische Filmbestand des Deutschen Hygiene-Museums Dresden', in Kamera! Licht! Aktion! Filme über Körper und Gesundheit 1915-1990, ed. by Susanne Rößiger and Uta Schwarz (Dresden: Sandstein, 2011), pp. 12-49.

Steinmetz, Rüdiger, 'Television History in Germany: Media-Political and MediaEthical Aspects', in German Television: Historical and Theoretical Approaches, ed. by Larson Powell and Robert Shandley (New York: Berghahn, 2016), pp. 133-154. Ulbricht, Walter, 'Antwort auf aktuelle Fragen der Jugend: Aus der Rede von Walter Ulbricht auf dem V. Parlament der Freien Deutschen Jugend am 26. Mai 1955', Junge Welt, 9, 143 (18/19 June 1955), p. 3.

Walsh, Martin, The Brechtian Aspect of Radical Cinema, ed. by Keith M. Griffiths (London: British Film Institute, 1981).

Winkler, Anita, 'Biology, Morality and Gender: East and West German Sex Education in Films, 1945-70' (PhD thesis, Durham University, 2014).

Witzlack, Gerhard, Beiheft zum Lehrerbildungsfilm: Begegnung mit dem anderen Geschlecht III: Weil ich kein Kind mehr bin, T-IF63, ed. by Deutsches Zentralinstitut für Lehrmittel, Berlin (Berlin: Volk und Wissen, 1964).

Wulff, Hans Jürgen, 'Verfremdungseffekt', in Lexikon der Filmbegriffe, 12 October 2012, http://filmlexikon.uni-kiel.de/index.php?action=lexikon\&tag=det\& $\mathrm{id}=\mathbf{1 5 7 4}$, accessed 20 July 2015.

Z., 'Beiträge in Edinburgh', Neue Zeit, 20, 205 (2 September 1966), p. 4.

\section{About the Author}

PD Dr. Anja Laukötter is a historian of nineteenth- and twentieth-century European history working in the field of social and cultural history and history of science. She is a researcher at the Center for the History of Emotions at the Max Planck Institute for Human Development and co-principal investigator of the ERC Advanced grant BodyCapital. In addition to other subjects, the main field of her research is the transnational/global history of media, the history of emotions, and the history of psychology and pedagogy. Contact details: laukoetter@mpib-berlin.mpg.de 